\title{
PUMPED-HYDRO STORAGE SYSTEMS AND FLOOD RISK MITIGATION: A PROPOSED NEXUS
}

\author{
OLUSEYE A. ADEBIMPE ${ }^{1}$, DAVID PROVERBS ${ }^{2} \&$ VICTOR O. OLADOKUN $^{1}$ \\ ${ }^{1}$ Department of Industrial and Production Engineering, University of Ibadan, Nigeria \\ ${ }^{2}$ Faculty of Computing, Engineering and the Built Environment, Birmingham City University, Birmingham, UK
}

\begin{abstract}
Pumped-Hydro Storage (P-HS) technology has received some significant attention in energy storage. However, its application towards flood risk mitigation is a new dimension, which merits consideration given some of the technical characteristics and the system's components. This study draws on a synthesis of the existing body of knowledge to postulate the potential nexus between P-HS operation and flood risk mitigation. This study represents the first attempt to explore the potential application of P-HS towards mitigating flood risk and also considers some of the other multiple benefits. The study raises a number of questions and considerations including, for example, what is the link between energy storage and flood risk mitigation?; what are the key areas that require consideration for the application of P-HS in flood risk mitigation?; how can the development of P-HS benefit flood risk mitigation? and how can this be achieved in a way that draws the interests of stakeholders and investors? A conceptual framework that seeks to establish these links alongside key areas that require consideration in line with the proposed application of P-HS in flood risk mitigation is presented. Thereafter, a discussion of the multiple benefits that P-HS could provide is presented, including improved environmental resilience as well as wider economic benefits.
\end{abstract}

Keywords: Flood Risk Mitigation, Energy Storage, Flood, Pumped-Hydro Storage.

\section{INTRODUCTION}

Flooding is regarded as the most damaging natural hazard globally [1], [2] with increased frequency of flood events having major agricultural, economic, environmental, social and physical effects across many countries [3], [4]. Globally, more than 500,000 people have been killed by flooding and more than 650 million have been displaced in the last 35 years with billions of dollars being lost [5], [6]. Traditional flood risk mitigation methods such as protective walls, dykes, canals and hard infrastructures are becoming unsustainable and inadequate in many flood scenarios. The magnitude and increasing frequency of flood disasters events demand innovative policy and strategic approaches. Hence, recent thinking and policy are shifting towards the adoption of more integrated flood risk management (FRM) approaches in many countries, including Germany and the United Kingdom [7].

These integrated approaches allow more sustainable ways of reducing the risk of flooding through adaptive planning and accepting that some flooding is inevitable. They also attempt to address other related challenges in achieving multiple benefits, including the conservation of energy and water, providing habitat for wildlife and improved water quality (see, for example, Talebpour et al.; Sahin et al. [8], [9]). One of such integrated systems revolves around the use of pumped-hydro storage (P-HS) systems for both energy conservation and flood risk mitigation. However, there appears to be a dearth of research in this domain.

This study draws on a synthesis of the existing body of knowledge to postulate the potential nexus between P-HS operation and flood risk mitigation. The study also considers the opportunity for the provision of other multiple benefits that might be of consequence. A conceptual framework is described representing the key interrelationships within the nexus and highlights some key areas that need to be considered. 


\section{PUMPED-HYDRO STORAGE TECHNOLOGY}

P-HS are an energy storage technology and a mechanical energy storage system that stores electrical energy and dispatches it when required using the energy of water [10]. The system operates by pumping water from a lower reservoir to the upper reservoir and on-demand releases water through a hydro turbine [11]. P-HS is a form of clean energy storage, able to respond quickly to changes in demand, and can provide a long-term, large storage capacity, which has wider application in the domain of energy supply [12]. In light of these features, a potential application of P-HS is the adaptation of its facilities and operation to support flood risk mitigation. However, this concept has received scant attention in the existing body of literature with a dearth of information on the potential of P-HS in flood risk mitigation.

\section{FLOODING}

Flooding is the manifestation of unwanted water in a normally dry environment [13] and can lead to damages of critical infrastructure and the built environment, disruption to communities and in some cases fatalities. Causes of flooding include factors such as growth in population, urbanization and industrialization [14], [15]. Other factors include global warming, climate change and anthropogenic activities. These have led to storm surges, sea-level rise and excess and irregular rainfall patterns [16], [17], initiating more frequent and severe flooding. For example, Syvitski et al. [18] observed the increase in riverine flooding and inland flooding in India as a result of climate change, leading to the flooding of delta cities, such as in Ganges, Brahmani, Mahanadi, Krishna and Godavari.

However, various types of flooding exist owing to different causal factors and/or the nature of the environment [19]. For example, flash flooding occurrence is described as a response to rainfall and mostly experienced in areas with steep slopes during heavy downpours, while coastal flooding results from the result of severe coastal storms and sea level rise [20]. Fluvial flooding is experienced when river banks are overtopped and submerge floodplains, which are normally dry [21]. Considering the difference in causes and severity of flooding, a single approach to FRM is unlikely to be applicable in mitigating the risk of all types of flooding. Therefore, any proposed method towards mitigating flooding should demonstrate its capability for flood risk mitigation either by the way of its function in a related operation and/or its system components. To this end, P-HS appears to be mostly applicable for mitigating fluvial flooding.

\section{FRM}

FRM seeks ways to manage the interacting elements that can cause and/or be at risk during a flood event. FRM incorporates measures, which allow the built environment to cope and make space for water during flood events [22]. Thus, it is now generally regarded to have four main elements of prevention, preparation, response and recovery [23], [24].

Prevention considers ways of avoiding flooding through pre-flood event activities. This includes measures that tend to reduce the chances of its occurrence, which covers both structural and non-structural approaches [25]. In the case of preparation, the concept understands the challenges of completely eradicating flooding. However, it draws on various concepts to minimize the aftermath of flood occurrence. Since flooding cannot be totally eradicated, various efforts under preparation will lead to coping measures and to ease off shocks [26]. Response refers to the measures taken during the events to limit the adverse effects of flooding on the environment. Although these elements of FRM indicate avoidance and preparation strategies, the residual risks cannot be underestimated. Response considers activities that 
react during flooding with immediate measures to reduce the duration and the adversity [27]. Therefore, well-defined approaches will minimize the impacts of flooding on, for example, communities and critical infrastructure. Recovery entails the steps taken towards the repair or restoration to the initial state before the flood events. This element is methods that enhance the resilience of the affected environment within a reasonable time. The toughening of the affected area against similar occurrences in the future is also considered within this element. Thus, all the elements of FRM are directed towards mitigating flood risk.

Flood risk mitigation is part of the strategies within the FRM discourse, which is premised on the notion that diverse strategies of adaptation and managing flood risk is required [28]. That is, flood risk mitigation is targeted at offering various strategies that minimizes the magnitude of water threat through various suitable measures for water accommodation [29], such as flood storage areas, sustainable urban drainages (SUDs), etc. Thus, flood risk mitigation approach is all encompassing in the sense that it allows for many combined efforts towards flood mitigation.

In the light of this, some links were observed within the strategies of flood risk mitigation and P-HS characteristics. First, both flood risk mitigation and P-HS operations are hydrologically related, and second, they have some matching operations and components. For instance, flood water control, detaining and regulation of flow processes in flood risk mitigation are similar to the water conservation and dispatch processes in P-HS operation. Also, components such as reservoirs and pumps that are useful in flood risk mitigation are required for a P-HS scheme. Therefore, this implies that both processes share basic features and characteristics, suggesting the potential for integration.

\section{CONCEPTUAL FRAMEWORK}

A conceptual framework to describe the proposed nexus of P-HS in flood risk mitigation is presented in Fig. 1. Our thoughts on the links and three main areas that are considered necessary and require investigation will now be explained. In the figure, P-HS technology is represented as a facility to address the two themes of the framework namely energy storage and flood risk mitigation.

The first key theme of the framework is energy storage, which is the primary function for which P-HS is known. This operation involves the storage of energy for later distribution when demanded. This operation aids in energy availability and grid resilience [30], which are fundamental to the growth and sustainability of a nation's economy [31].

Flood risk mitigation is the second theme of the framework. Flood risk mitigation as previously discussed involves various flood management procedures and flood water control. It is observed that flood risk mitigation is achievable through the direct deployment of P-HS components for flood control, such as the deployment of the upper and lower reservoirs [32], [33] for flood water storage, regulation of flood water and reduction of flood peaks. One of the basic requirements for the development of P-HS is reservoirs, which are separated with differential height. The size of the reservoir and the volume of water required for the operation are the functions of the energy to be stored. However, at any point of energy storage operation, the two reservoirs are not filled to capacity at the same time, thus making way for the reservoirs to be used as storage for flood waters. For example, each of the upper and lower reservoirs for mini energy storage of about $250 \mathrm{~kW}$ is about $24000 \mathrm{~m}^{3}$ for head within $70 \mathrm{~m}$ [34], while large energy storage could require upper and lower reservoirs ranging into millions of cubic meters. In such a case, we suggest that the spare capacity within the reservoir alongside other components such as pumps avails an opportunity to support flood risk 


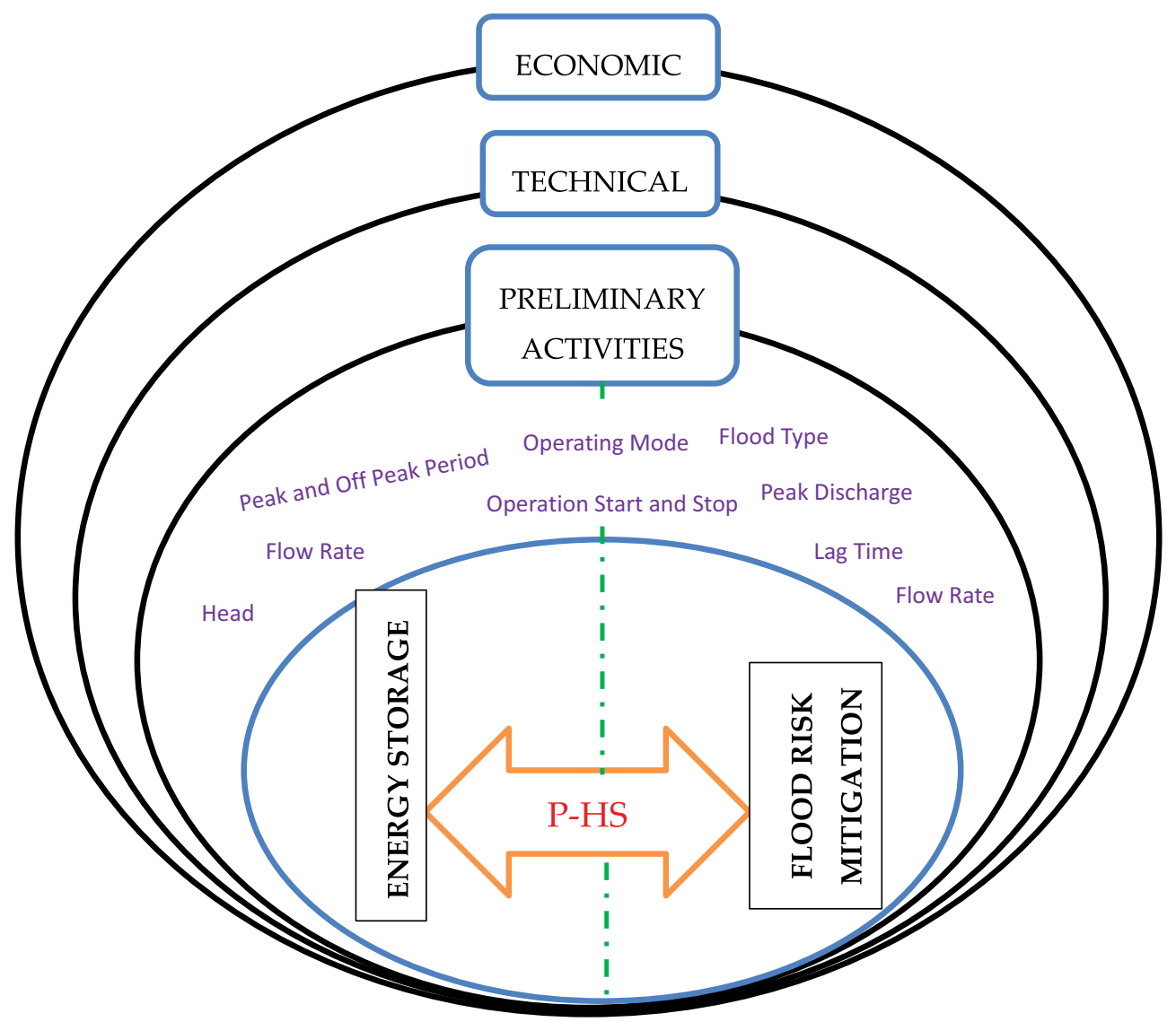

Figure 1: A conceptual framework for the proposed nexus of pumped-hydro storage in flood risk mitigation (author's concept)

mitigation. The pump, in this case, is to aid the transfer of water from the lower to the upper reservoir to make capacity for the collection of flood water in the lower reservoir. Through this, the flood water can be accommodated and detained for some time within the lower reservoir.

However, to achieve these two themes, some preliminary activities are considered important. These activities that are fundamental to the purpose of the system include the determination of the site for the proposed system, location of reservoirs (upper and lower), energy source for pumping and operational characterization. To develop a P-HS system, the first consideration is the site to be developed: The location has to favour P-HS operation in a floodprone area. Thus, a survey to characterize the flood-prone areas, the type of flooding and the suitability of the site for P-HS is required. Such characterization include determining if the type of flood to be mitigated is within the capacity of the proposed system, and determining if the topography, spatial and hydrological characteristics of the ecological systems meet P-HS design requirements. Ecological resource considerations such as topographic features (valleys, hills, etc.) and fluvial characteristics are examples of determinants of the location of the P-HS. Likewise, decisions on choice of reservoirs (i.e. natural or artificial), possible methods 
to direct flood water to the reservoirs and/or capture flood water has to be made based on the available resources in the area. For instance, whether there is an existing drainage system or connecting conduits that can easily be linked up to direct the flood water.

Meanwhile, the capacity of the reservoirs for the proposed system should be carefully considered to avoid any form of mismatch or failure of the scheme. Thus, factors that influences P-HS reservoirs capacities such as energy storage capacity, head, duration of storage and flow rate [35] are to be considered alongside the projected volume of flood water to determine the capacity of the reservoir for the proposed scheme. By this, a reasonable volume of flood water would be adequately catered for within the reservoirs during construction. Hence, reservoir construction for this purpose can be achieved through damming, excavating or embankments depending on the proposed location.

The energy source for pumping should be made available using energy from a renewable source in order to avoid any element that can cause further damage to the environment. A renewable source such as wind, solar energy and/or any other clean energy source that is abundant within the location of interest is suggested for pumping. P-HS can work sufficiently with solar and wind [11].

Another part of the preliminary activities is the characterization of P-HS operations. This is a fundamental process in the design of a functional system. By characterizing the operation, a better understanding of the systems for operation, planning, scheduling, operational rules and procedures for flood control (see Zhou et al. [36]) can be achieved.

The operational rules in this case should allow for the seamless integration of the two functions. That is, the flood characteristics have to be observed and characterized in such a way that during flooding, P-HS deploys its facility for storing flood water and releases it at a much-controlled rate after the risk has passed. Thereafter, when the flooding period is over, the system should resume back to its energy storage function. Such an effective operation characterization would represent a well-coordinated system and can be easily translated into some kind of control and automation. In Table 1, the factors that can influence the operational characterization in the two themes have been suggested. Thus, further research is proposed to determine the principal factors, the parameters and the variables and their specific influence on each of the two themes.

The technical aspects of a system are an important area that covers the basic structure, components and the set-up of the proposed system. Other aspects include the technical knowhow of the operation of the themes, as well as guides to measure the system performance such as efficiency, effectiveness, and/or reliability. Currently, an understanding of the technical aspects of P-HS has been established. However, the technicalities involved with applying flood risk mitigation in P-HS appear to be at the early stage of conceptualization and requires an understanding of the technical relationship and scientific methods involved. By this, an adequate analysis of the operating scenarios as well as the ability to manipulate the technical features can be developed, prior to developing a physical system.

The third area that is regarded as valuable for the proposed system is the economic considerations. This is a pivotal aspect of the development and sustainability of a system. In developing P-HS, the capital cost is high but with very low operation and maintenance and replacement cost [23]. However, it would be appropriate to understand how the incorporation of the flood risk mitigation function would impact the cost of P-HS. Thus, an economic consideration of the proposed system is required to understand this aspect and to ascertain the economic viability of the scheme. In this regard, we suggest a cost-benefit approach (CBA) as an appropriate economic measure for the proposed system because of its applicability in evaluating both monetary and non-monetary benefits [42]. 
For the costing aspect of the proposed system, a comprehensive costing of components of both themes is to be performed. Thus, we recommend a lifecycle costing methodology as an appropriate method for capturing all the associated cost from the initial cost, operation and maintenance to replacement cost. This would help to conceptualize the entire cost

Table 1: Relevant factors for the operational characterization

\begin{tabular}{|c|c|c|c|}
\hline Factors & $\begin{array}{l}\text { Releva } \\
\text { theme }\end{array}$ & & Description \\
\hline & 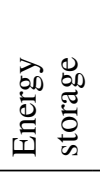 & 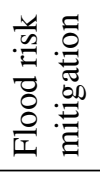 & \\
\hline $\begin{array}{l}\text { Flow rate (pump and } \\
\text { turbine) }\end{array}$ & & $\sqrt{ }$ & $\begin{array}{l}\text { This describes the rate at which water is ex- } \\
\text { changed between the upper and lower reser- } \\
\text { voirs during the pumping and discharging and } \\
\text { how quick the extra capacity of the reservoir } \\
\text { to be used for flood water storage should be } \\
\text { made available. }\end{array}$ \\
\hline $\begin{array}{l}\text { Start and stop time of } \\
\text { operations }\end{array}$ & & $\sqrt{ }$ & $\begin{array}{l}\text { This refers to the planned time for the opera- } \\
\text { tion of charging and discharging of pumping } \\
\text { and generating as well as the period of the } \\
\text { operation of each of the themes. }\end{array}$ \\
\hline Storage volume & & $\sqrt{ }$ & $\begin{array}{l}\text { This describes the capacity of the reservoirs } \\
\text { and the volume of flood water that can be } \\
\text { contained within it. }\end{array}$ \\
\hline Head & $\sqrt{ }$ & & $\begin{array}{l}\text { This is the differential height between the up- } \\
\text { per and lower reservoirs. }\end{array}$ \\
\hline Off-peak and peak period & $\sqrt{ }$ & & $\begin{array}{l}\text { This refers to the period in which the load } \\
\text { system depends on the energy storage and/or } \\
\text { the period in which excess energy from the } \\
\text { grid or a renewable source is supplied to the } \\
\text { energy storage. }\end{array}$ \\
\hline $\begin{array}{l}\text { Hours of P-HS } \\
\text { availability }\end{array}$ & $\sqrt{ }$ & & $\begin{array}{l}\text { This describes the duration for which the } \\
\text { stored energy can serve the load system. That } \\
\text { is, the period of time for which energy from } \\
\text { the P-HS system is made available. }\end{array}$ \\
\hline Mode of operation & $\sqrt{ }$ & $\sqrt{ }$ & $\begin{array}{l}\text { This refers to the operation schedule of en- } \\
\text { ergy storage and the flood risk mitigation. }\end{array}$ \\
\hline Rainfall pattern & & $\sqrt{ }$ & $\begin{array}{l}\text { This describes the period and distribution of } \\
\text { rain within a specific time. This would help } \\
\text { to have a foreknowledge of the period when } \\
\text { the volume of rain could be high in order to } \\
\text { schedule the operation of P-HS. }\end{array}$ \\
\hline
\end{tabular}


Table 1: (Continued)

\begin{tabular}{|c|c|c|}
\hline Factors & $\begin{array}{l}\text { Relevant } \\
\text { theme }\end{array}$ & Description \\
\hline & 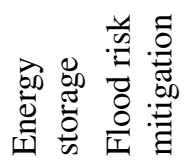 & \\
\hline $\begin{array}{l}\text { Flood characteristics, i.e. } \\
\text { flood type, flood veloc- } \\
\text { ity, flood duration, flood } \\
\text { depth, flood frequency, } \\
\text { lag time }\end{array}$ & $\sqrt{ }$ & $\begin{array}{l}\text { These describe the nature of the flood within } \\
\text { a specific environment. These characteris- } \\
\text { tics can influence the process of operation } \\
\text { characterization. For instance, to mitigate } \\
\text { river/fluvial flooding in lakes or river can be } \\
\text { worked on as a lower reservoirs for P-HS (for } \\
\text { example Wu et al.; Yao et al. [37], [38]) and } \\
\text { this process may require the highlighted flood } \\
\text { characteristics for operational characteriza- } \\
\text { tion. These would collectively assist in opera- } \\
\text { tion planning towards the period of the year } \\
\text { when flood can occur, and to schedule the } \\
\text { P-HS facility for such period. The lag time } \\
\text { describes the time between the rainfall peak } \\
\text { and the flood peak. This would help to have a } \\
\text { prior knowledge of the probable time to start } \\
\text { flood risk mitigation operation. }\end{array}$ \\
\hline Peak discharge & $\sqrt{ }$ & $\begin{array}{l}\text { This refers to the maximum flood water } \\
\text { discharge. This would assist in operation } \\
\text { planning and to prepare the facilities for flood } \\
\text { risk mitigation during peak period. }\end{array}$ \\
\hline
\end{tabular}

Source: [39], [40], [41]

of the proposed system and each function. Such that, while the cost of the entire investment can be estimated, the estimated cost that goes into each function can also be determined. Also, a comprehensive investigation and methodology for the quantification of the benefits of the two themes should be considered. With this, the economic viability of the entire system can be justified and key decisions regarding the system can be made. That is, whether the proposed system and its general impact on the built environment are worth the estimated cost.

\section{IMPLICATION OF APPLYING P-HS IN FLOOD RISK MITIGATION}

The potential ways in which the development of P-HS could assist in flood risk mitigation are now highlighted. Applying P-HS offers opportunities to improve environmental resilience to flooding and may indirectly help to lower greenhouse gas and $\mathrm{CO}_{2}$ emissions [43]. Also, it has the capability to serve a back-up role should flooding disrupt energy generation plant or the grid. P-HS can be used to stand in to aid quick recovery. 
Many of the components that make up the P-HS system are applicable to FRM, and this include reservoirs (upper and lower), water conveyance system (penstock) and the pumps. The reservoirs that serve the purpose of storage in P-HS can serve to store flood water and act as a buffer. This can attenuate the flood and reduce the flood velocity, thus reducing the damages to properties and the environment. Also, other activities towards the development of $\mathrm{P}-\mathrm{HS}$ can be of benefit in mitigating flood. Such as the construction of reservoirs, modification of lakes and rivers to increase their capacity. This controls the fluvial flooding by creating more volume for water to prevent rivers from being overtopped. Other activities such as water channelization and flow regulation can be achieved during this process to re-direct and restrict the free flow of run-offs [44], [45].

Flood risk mitigation can demand considerable investment given the required resources to achieve the goal. Both structural and non-structural measures committed to the avoidance of flooding require large funds. Therefore, committing the bulk of resources to flood issues alone may be seemingly difficult because of other activities competing for these limited resources, for instance, mitigating flooding in the face of other structural development such as energy systems, roads and water systems. This could slow down the rate at which the built environment is made more resilient to flooding. However, P-HS has the potential to solve the problems simultaneously through self-finance or reduced cost of investment. The technology gives room for arbitrage services, which may help to recoup the money invested during its operating life. Thereby, leading to further opportunities to source and fund more flood risk mitigation measures. This is one of the P-HS applications and one of the reasons for its acceptability in energy management. It refers to its capacity in energy trading (i.e. buying energy at a period and selling it at another for profit) [29]. Investors may find this interesting and invest their money to collectively protect the environment. Such investment does not necessarily mean for profit-making alone but to support the government in mitigating flood. The return on the investment through arbitrage can offset the cost of developing such systems. Also, this is a kind of flexibility that can support loan application and repayments to further FRM interventions.

\section{CONCLUSIONS AND RECOMMENDATIONS}

In this study, we have proposed the potential nexus of P-HS and flood risk mitigation as an emerging concept. Being a newly conceived idea, we identified and discussed three key areas towards achieving this goal, namely preliminary activities, technical and economic considerations. Thus, this concept of a nexus between flood risk mitigation and P-HS is perceived as an approach that can benefit flood management.

An innovative linkage between P-HS and flood risk mitigation has been established in this research, and further studies would be in the following areas:

1. A techno-economic appraisal of the P-HS in this regard to give a qualitative and quantitative analysis of the benefits.

2. A technical methodology for the deployment of P-HS towards integrated energy storage and flood risk mitigation.

\section{ACKNOWLEDGEMENTS}

The authors acknowledge the support of Birmingham City University-Erasmus Plus Project and University of Ibadan through the Federal Government of Nigeria Revitalization Fund. 


\section{REFERENCES}

[1] Prajamwong, S. \& Suppataratarn, P. Integrated: flood mitigation management in the Lower Chao Phraya River Basin. In expert group meeting on innovative strategies towards flood resilient cities in Asia-Pacific, 2009.

[2] Herslund, L.B., Jalayer, F., Jean-Baptiste, N., Jørgensen, G., Kabisch, S., Kombe, W., Lindley, S., Nyed, P.K., Pauleit, S., Printz, A. \& Vedeld, T. A multi-dimensional assessment of urban vulnerability to climate change in sub-Saharan Africa. Nat. Hazards, 82, pp. 149$172,2016$.

[3] UN Water. 2018 UN World Water Development Report, Nature-based Solutions for Water. UNESCO, London, 2018. Online: https://unesdoc.unesco.org/ark:/48223/ pf0000261424. Accessed on 23 Apr., 2020.

[4] Teng, J., Jakeman, A.J., Vaze, J., Croke, B.F., Dutta, D. \& Kim, S. Flood inundation modelling: A review of methods, recent advances and uncertainty analysis. Environmental Modelling \& Software, 90, pp. 201-216, 2017.

[5] Kocornik-Mina, A., McDermott, T.K., Michaels, G. \& Rauch, F. Flooded cities. American Economic Journal: Applied Economic, 12, pp. 35-66, 2020.

[6] Tariq, M.A.U.R. \& Van de Giesen, N., Floods and flood management in Pakistan. Physics and Chemistry of the Earth Parts A/B/C, 47, pp. 11-20, 2012.

[7] Merz, B., Hall, J., Disse, M. \& Schumann, A., Fluvial flood risk management in a changing world. Natural Hazards and Earth System Sciences, 10, pp. 509-527, 2010.

[8] Talebpour, M.R., Sahin, O., Siems, R. \& Stewart, R.A., Water and energy nexus of residential rainwater tanks at an end use level: case of Australia. Energy Build, 80, pp. 195-207, 2014.

[9] Sahin, O., Siems, R., Richards, R.G., Helfer, F. \& Stewart R.A. Examining the potential for energy-positive bulk-water infrastructure to provide long-term urban water security: A systems approach. Journal of Cleaner Production, 143, pp. 557-566, 2017.

[10] Amirante, R., Cassone, E., Distaso, E. \& Tamburrano, P. Overview on recent developments in energy storage: Mechanical, electrochemical and hydrogen technologies. Energy Conversion and Management, 132, pp. 372-387, 2017.

[11] Guney, M.S. \& Tepe, Y. Classification and assessment of energy storage systems. Renewable and Sustainable Energy Reviews, 75, pp. 1187-1197, 2017.

[12] Ayodele, T.R. \& Ogunjuyigbe, A.S.O. Mitigation of wind power intermittency: Storage technology approach. Renewable and Sustainable Energy Reviews, 44, pp. 447-456, 2015.

[13] Adebimpe, O.A., Oladokun, Y.O.M, Odedairo, B.O., Oladokun, V.O., Developing Flood Resilient Buildings in Nigeria: A Guide. Journal of Environment and Earth Science, 8, pp. 143-150, 2018.

[14] Djordjević, S., Butler, D., Gourbesville, P., Mark, O. \& Pasche, E. New policies to deal with climate change and other drivers impacting on resilience to flooding in urban areas: the CORFU approach. Environmental Science \& Policy, 14, pp. 864-873, 2011.

[15] UNISDR. Global Assessment Report on Disaster Risk Reduction-Revealing risk, redefining development. Online, https://www.preventionweb.net/files/globalplatform/5198 f8ce8fe5bExecutive_Summary_Revealing_Risk,_Redefining_Development._Global_ Assessment_Report_on_Disaster_Risk_Reduction_2011.pdf, 2011. Accessed on: 26 Mar. 2020. 
[16] Meusburger, K. \& Alewell, C. Impacts of anthropogenic and environmental factors on the occurrence of shallow landslides in an alpine catchment (Urseren Valley, Switzerland). Natural Hazards and Earth System Sciences, 8, pp. 509-520, 2008.

[17] Schaller, N., Kay, A.L., Lamb, R., Massey, N.R., Van Oldenborgh, G.J., Otto, F.E., Sparrow, S.N., Vautard, R., Yiou, P., Ashpole, I. \& Bowery, A., Human influence on climate in the 2014 southern England winter floods and their impacts. Nature Climate Change, 6, pp. 627-634, 2016.

[18] Syvitski, J.P.M., Kettner, A.J., Overeem, I., Hutton, E.W., Hannon, M.T., Brakenridge, G.R., Day, J., Vörösmarty, C., Saito, Y., Giosan, L. \& Nicholls, R.J. Sinking deltas due to human activities. Nature Geoscience, 2, pp. 681-686, 2009.

[19] FLOODsite. Flood Types. Online, http://www.floodsite.net/juniorfloodsite/html/en/student/thingstoknow/hydrology/floodtypes.html, 2020. Accessed on: 22 Apr. 2020.

[20] Ngo, T.T., Yoo, D.G., Lee, Y.S. \& Kim, J.H., Optimization of upstream detention reservoir facilities for downstream flood mitigation in urban areas. Water, 8, pp. 290, 2016.

[21] Chen, A.S., Djordjević, S., Leandro, J. \& Savić, D.A. An analysis of the combined consequences of pluvial and fluvial flooding. Water Science and Technology, 62, pp. 1491-1498, 2010.

[22] Schelfaut, K., Pannemans, B., Van der Craats, I., Krywkow, J., Mysiak, J. \& Cools, J., Bringing flood resilience into practice: the FREEMAN project. Environmental Science \& Policy, 14, pp. 825-833, 2011.

[23] DKKV. German Committee for Disaster Prevention ed.; 2003 Hochwasservorsorge in Deutschland. Lernen aus der Katastrophe 2002 im Elbegebiet. DKKV-Report 29, Bonn, Germany, pp. 36, 2003.

[24] Thieken, A.H., Kreibich, H., Müller, M. \& Merz, B., Coping with floods: preparedness, response and recovery of flood-affected residents in Germany in 2002. Hydrological Sciences Journal, 52, pp. 1016-1037, 2007.

[25] Meyer, V., Priest, S. \& Kuhlicke, C., Economic evaluation of structural and nonstructural flood risk management measures: examples from the Mulde River. Natural Hazards, 62, pp. 301-324, 2012.

[26] Schanze, J., Flood risk management - a basic framework. In: Flood Risk Management: Hazards, Vulnerability and Mitigation Measures, Schanze, J.; Zeman, E.; Marsalel, J. Eds.; Springer: Dordrecht, Netherlands, 67, pp. 1-20, 2006.

[27] Fournier, M., Larrue, C., Alexander, M., Hegger, D., Bakker, M., Pettersson, M., ... \& Chorynski, A., Flood risk mitigation in Europe: how far away are we from the aspired forms of adaptive governance?. Ecology and Society, 21, pp. 49, 2016.

[28] Hegger, D.L.T., Driessen, P.J.P., Dieperink, C., Wiering, M., Raadgever, G.T.T. \& van Rijswick, H.F.M.W. Assessing stability and dynamics in flood risk governance. Water Resources Management, 28, pp. 4127-4142, 2014.

[29] Thieken, A.H., Kienzler, S., Kreibich, H., Kuhlicke, C., Kunz, M., Mühr, B., Müller, M., Otto, A., Petrow, T., Pisi, S. \& Schröter, K., Review of the flood risk management system in Germany after the major flood in 2013. Ecology and Society, 21, pp. 51-64, 2016.

[30] Rehman, S., Al-Hadhrami, L.M. \& Alam, M.M., Pumped hydro energy storage system: A technological review. Renewable and Sustainable Energy Reviews, 44, pp. 586-598, 2015.

[31] Adebimpe, O.A. \& Oladokun, V.O., Relevance of Energy storage Technology in the Development of Solar Power. Journal of Energy technologies and Policy, 9, pp. 20-27, 2019. 
[32] Deane, J.P., Gallachóir, B.Ó. \& McKeogh, E.J. Techno-economic review of existing and new pumped hydro energy storage plant. Renewable and Sustainable Energy Reviews, 14, pp. 1293-1302, 2010.

[33] Morán-Tejeda, E., Lorenzo-Lacruz, J., López-Moreno, J.I., Ceballos-Barbancho, A., Zabalza, J. \& Vicente-Serrano, S.M. Reservoir management in the Duero Basin (Spain): impact on river regimes and the response to environmental change. Water resources management 26, pp. 2125-2146, 2012.

[34] Alqub, M. Design and Life Cycle Assessment of Pumped Hydro Energy Storage System for Nablus Western Wastewater Treatment Plant. Master Thesis, An-Najah National University, Palestine, 2017.

[35] Akour, S.N. \& Al-Garalleh, A.A. Candidate Sites for Pumped Hydroelectric Energy Storage System in Jordan. Modern Applied Science, 13, pp. 116-131, 2019.

[36] Zhou, Y.L., Guo, S., Xu, C.Y., Liu, P. \& Qin, H., Deriving joint optimal refill rules for cascade reservoirs with multi-objective evaluation. Journal of Hydrology, 524, 166-181, 2015.

[37] Wu, Y., Zhang, T., Xu, C., Zhang, X., Ke, Y., Chu, H. \& Xu, R., Location selection of seawater pumped hydro storage station in China based on multi-attribute decision making. Renewable energy, 139, pp. 410-425, 2019.

[38] Yao, W., Deng, C., Li, D., Chen, M., Peng, P. \& Zhang, H., Optimal Sizing of Seawater Pumped Storage Plant with Variable-Speed Units Considering Offshore Wind Power Accommodation. Sustainability, 11, pp. 1939, 2019.

[39] Bueno, C. \& Carta, J.A., Technical-economic analysis of wind-powered pumped hydro storage systems. Part I: model development. Solar Energy, 78, pp. 382-395, 2005.

[40] Adedeji, T.J., Proverbs, D.G., Xiao, H., Oladokun, V.O., Towards a conceptual framework for property level flood resilience. International journal of safety and security engineering, 8, pp. 493-504, 2018.

[41] Adedeji, T.J., Proverbs, D.G., Oladokun, V.O. \& Xiao, H., Making Homes More Resilient to Flooding: A New Hybrid Approach. In: Resilient Structures and Infrastructure, Noroozinejad Farsangi E.; Takewaki I.; Yang T.; Astaneh-Asl A.; Gardoni P. Eds.; Springer, Singapore, pp. 159-176, 2019.

[42] Oladunjoye, O.A., Proverbs, D.G., Collins, B. \& Hong, X., A cost-benefit analysis model for the retrofit of sustainable urban drainage systems towards improved flood risk mitigation. International Journal of Building Pathology and Adaptation, DOI 10.1108/IJBPA-12-2018-0105, 2019.

[43] Lu, B., Blakers, A. \& Stocks, M., 90-100\% renewable electricity for the south west interconnected system of Western Australia. Energy, 122, pp. 663-674, 2017.

[44] Qi, Y., Yu, J., Li, X., Wei, Y. \& Miao, Q., Reservoir flood control operation using multi-objective evolutionary algorithm with decomposition and preferences. Applied Soft Computing, 50, pp. 21-33, 2017.

[45] Liao, K.H., Chan, J.K.H. \& Huang, Y.L., Environmental justice and flood prevention: The moral cost of floodwater redistribution. Landscape and Urban Planning, 189, pp. 36-45, 2019. 